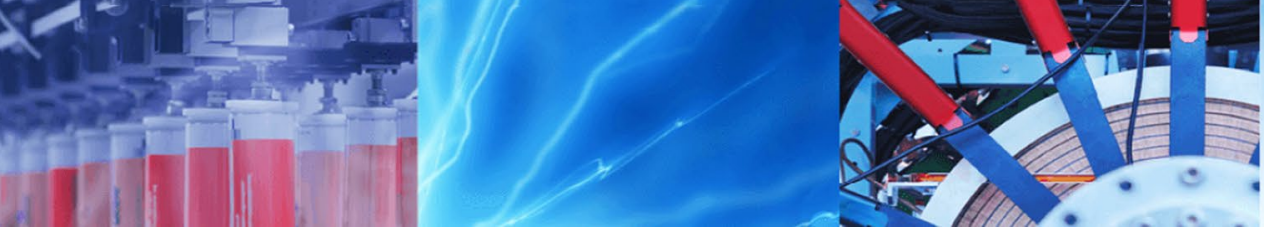

Research Article

\title{
Behavior of foamed concrete reinforced with hybrid fibers and exposed to elevated temperatures
}

\author{
Eethar Thanon Dawood ${ }^{1}$ [ - Alyaa Abbas Alattar ${ }^{2} \cdot$ Waleed Abdulrazzak Abbas $^{3} \cdot$ Yahya Ziad Mohammad $^{4}$
}

Received: 18 June 2019 / Accepted: 5 December 2019 / Published online: 14 December 2019

(c) Springer Nature Switzerland AG 2019

\begin{abstract}
This paper demonstrates the behavior of foamed concrete reinforced with either or both carbon fibers and polypropylene fibers exposed to elevated temperatures. Various volumetric fractions of carbon fibers $(0.5,1$ and $1.5 \%)$ were used to reinforce foamed concrete mix. Also, hybrid fibers of carbon fibers (CF) and polypropylene fibers (PPF) as $1 \% \mathrm{CF}+0.5 \%$ PPF and $0.5 \% \mathrm{CF}+1 \% \mathrm{PPF}$ were prepared. Lastly, the mono polypropylene fibers as $1.5 \%$ PPF were used to reinforce the foamed concrete mix. These different mixes were tested, compressive strength, splitting tensile strength, flexural strength and flexural toughness tests. Besides, the heating procedure of the specimens was done by applying them to different burning degrees, which were $200,250,300,350$ and $400^{\circ} \mathrm{C}$. The results illustrated that the compressive and flexural tensile strengths of lightweight foamed concrete (LWFC) decreased with the increasing temperature. However, the highest effects on these strengths appeared once the temperature raised to $400^{\circ} \mathrm{C}$. The LWFC mix reinforced with polypropylene fiber exhibits more sensitive to elevated temperature than LWFC mixes reinforced with carbon fiber due to low melting point of polypropylene fiber.
\end{abstract}

Keywords Foamed concrete $\cdot$ Hybrid fibers · Toughness · Fire resistance

\section{Introduction}

Foamed concrete (FC) can be represented as one of the most developed materials in concrete technology that can widely be used in construction projects. Significant enhancements over the past 20 years in production equipment and better quality surfactants (foaming agents) has enabled the use of foamed concrete on a larger scale [1,2]. The use of structural lightweight foamed concrete (SLWFC) which possesses good mechanical properties and durability ensures many benefits. Thus, SLWFC is a relatively new construction material which provides more efficient strength-to-weight ratio in structural elements. Concrete has inherently brittle nature and some disadvantages such as poor deformation and weak crack resistance in the practical usage. The fibers are used for overcoming the brittleness of lightweight foamed concrete [3]. The hybridization of different fibers may offer potential advantages in improving concrete properties. Hybrid fibers can offer reinforcement at all ranges of strains. The combination of low and high modulus fibers can arrest cracks at the micro level as well as macro level. Most of the studies on LWFC have focused on its normal temperature properties only, and a very few of its thermal properties $[4,5]$. Song and Yin [6] studied the hybridization of carbon fiber and steel fiber could enhance the concrete performance in macro-crack bridging and micro-crack delaying. Steel fibers (SF) and carbon fibers (CF) can significantly increase the compression toughness of concrete. The use of hybrid fiber in high strength lightweight aggregate concrete

Eethar Thanon Dawood, eethar2005@yahoo.com | ${ }^{1}$ Building and Construction Department, Technical College of Mosul, Northern Technical University, Mosul, Iraq. ${ }^{2}$ Northern Technical University, Mosul, Iraq. ${ }^{3}$ Building and Construction Engineering, University of Technology, Baghdad, Iraq. ${ }^{4}$ Building and Construction Department, Technical College of Mosul, Mosul, Iraq. 
(HSLWAC) specimens show significant increase in splitting tensile strength and flexural strength compared with concrete specimens reinforced with $1 \%$ volume fraction of mono fiber. The percentage of increase in splitting tensile strength for hybrid fiber $(0.75 \mathrm{SF}+0.25 \mathrm{CF})$ up to $433 \%$, while the percentage of increase in flexural strength is about $65 \%$ compared with the plain specimens. Dawood and Hamad [7], have also studied the LWFC reinforced with hybrid fibers using different percentages of glass and polypropylene fibers. The authors have found that the use of " $0.4 \%$ glass fiber $+0.6 \%$ polypropylene fiber" has shown the best performance of LWFC. The results show highest increment in mechanical properties among other hybrid fibers mixes. Such increments were $21.5 \%, 16.7 \%$ and $36 \%$ for the compressive, flexural strength and splitting tensile, respectively. In regular concrete, the loss of strength due to high temperature is influenced primarily by the type of cement and the type of aggregate. Lightweight foamed concrete has a very good fire resistance and it shows a better performance than normal weight concrete at higher temperatures. On the first step of heating, the LWFC starting lost the absorbed, evaporable (free) water and then the chemically bound water. This loss of water would induce micro cracking that causing some reduction in strength of LWFC.

The reduction in compressive strength of LWFC between 20 and $150^{\circ} \mathrm{C}$ corresponds to a decrease of the cohesion of the Van der Waal forces between the calcium silicate hydrate layers and leads to the formation of saline groups ( $\mathrm{Si}-\mathrm{OH}: \mathrm{OH}-\mathrm{Si}$ ) that offers weaker bonding strength $[8,9]$.

Mydin and Wang [5] have also studied the mechanical properties of LWFC Subjected to elevated temperatures up to $600^{\circ} \mathrm{C}$. The strength of LWFC was slightly reduced at $200{ }^{\circ} \mathrm{C}$ and the compressive strength of the samples still retained about $94 \%$ of the original value. At a stage of heating $200^{\circ} \mathrm{C}$ to $400{ }^{\circ} \mathrm{C}$, decomposition of C-S-H gel and the sulfoaluminate phases caused cracks in the specimens that cause significant effects on the strength of LWFC. When the temperature reaches to $400^{\circ} \mathrm{C}$, the residual strength of LWFC only about $75 \%$ of its initial value. When temperature up to $600{ }^{\circ} \mathrm{C}$, the LWFC retained only about $40 \%$ of the original strength. The high air content in lightweight foamed concrete makes it suitable for use as firewalls.

Carbon fibers can improve the performance of the lightweight concrete at elevated temperature as shown in Plate 1. It can be seen clearly, that the carbon fibers existed after the temperature reached to $800^{\circ} \mathrm{C}$ [9].

However, it can be concluded that there is still an obvious lack in the researches related to the use of LWFC reinforced with carbon or hybrid fibers. Also, the few studies related to the thermal properties of LWFC encourage the

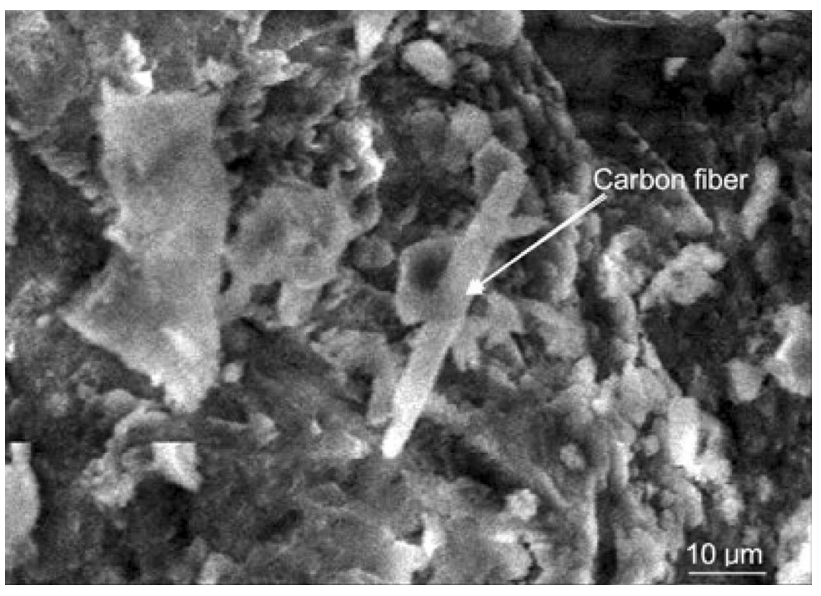

Plate.1 Scanning electron microscope image of the lightweight concrete with $1 \%$ mass fraction of carbon fibers after exposure to $800^{\circ} \mathrm{C}[9]$

Table 1 Physical properties of cements

\begin{tabular}{lll}
\hline Physical properties & Results & Limits of IQS: $5 / 1984$ \\
\hline Initial setting time (minute) & 100 & $\geq 45 \mathrm{~min}$ \\
Final setting time (minute) & 320 & $\leq 600 \mathrm{~min}$ \\
Fineness (Blaine $\left.\mathrm{m}^{2} / \mathrm{kg}\right)$ & 300 & $\geq 230\left(\mathrm{~m}^{2} / \mathrm{kg}\right)$ \\
$\begin{array}{l}\text { Soundness by Autoclave Method } \\
\quad \% \text { ) }\end{array}$ & 0.02 & Not more than 0.8 \\
$\begin{array}{l}\text { Compressive strength }(\mathrm{MPa}) \\
\begin{array}{l}\text { 3 days } \\
\text { 7 day }\end{array}\end{array}$ & 21 & $\geq 15$ \\
\hline
\end{tabular}

researchers to consider more studies covering such area. Therefore, this study was prepared to use carbon fibers and combination of carbon and polypropylene fibers with foamed concrete. These different mixes were tested and evaluated due to the application of elevated temperatures on the specimens produced from such foamed concrete.

\section{Materials}

The materials used in the present work are: cement, sand, water, silica fume, foam agent, carbon and polypropylene fibers.

Ordinary Portland cement (OPC) type (I) commercially known as AL-Mass cement factory (Al-Sulaimaniyahcity of Iraq) was used in this study. The physical characteristics of ordinary Portland cement are shown in Table 1 and it conforms to IQS: 5/1984 [10]. While, the chemical compositions of the cement have also conformed to IQS: 5/1984 and are shown in Table 2. Silica fume (Sika Fume HR) was used as a partial replacement of cement and its properties are presented in Table 3. 
Table 2 Chemical composition of cement

\begin{tabular}{|c|c|c|c|}
\hline Composition & Abbreviation & $\begin{array}{l}\text { Percentage by } \\
\text { weight }\end{array}$ & $\begin{array}{l}\text { Limits } \\
\text { of IQS: } \\
5 / 1984\end{array}$ \\
\hline Lime & $\mathrm{CaO}$ & 61 & - \\
\hline Silica & $\mathrm{SiO}_{2}$ & 19.84 & - \\
\hline Alumina & $\mathrm{Al}_{2} \mathrm{O}_{3}$ & 5.08 & - \\
\hline Iron oxide & $\mathrm{Fe}_{2} \mathrm{O}_{3}$ & 4.8 & - \\
\hline Sulphate & $\mathrm{SO}_{3}$ & 2.49 & $\leq 2.8$ \\
\hline Potash & $\mathrm{K}_{2} \mathrm{O}$ & 0.1 & \\
\hline Soda & $\mathrm{Na}_{2} \mathrm{O}$ & 0.3 & \\
\hline Equivalent $\mathrm{Na}_{2} \mathrm{O}$ & $\mathrm{Na}_{2} \mathrm{O}+0.658 \mathrm{~K}_{2} \mathrm{O}$ & 0.36 & $\leq 0.6 \%$ \\
\hline Magnesia & $\mathrm{MgO}$ & 2.48 & $\leq 5.0 \%$ \\
\hline Loss on ignition & L.O.I. & 3.8 & $\leq 4.0 \%$ \\
\hline Insoluble residue & I.R. & 0.40 & $\leq 1.5 \%$ \\
\hline \multicolumn{4}{|c|}{ Main compounds (Bogue's equations) } \\
\hline Tri calcium silicate & $\mathrm{C}_{3} \mathrm{~S}$ & 49.45 & - \\
\hline Di calcium silicate & $\mathrm{C}_{2} \mathrm{~S}$ & 19.57 & - \\
\hline Tri calcium aluminate & $\mathrm{C}_{3} \mathrm{~A}$ & 5.34 & - \\
\hline Tetra calcium aluminate -ferrite & $\mathrm{C}_{4} \mathrm{AF}$ & 14.61 & - \\
\hline
\end{tabular}

Table 3 Material properties of Silica fume

\begin{tabular}{ll}
\hline Form & Agglomerated \\
\hline Particles color/appearance & Grey \\
Specific gravity & 2.20 \\
Size of particles & $0.1 \mu$ \\
Dosage & $2-10 \%$ by \\
& weight of \\
Chloride content & cement
\end{tabular}

Table 4 Grading of fine aggregate

\begin{tabular}{lll}
\hline Sieve no. $(\mathrm{mm})$ & Passing (\%) & $\begin{array}{l}\text { Limits of } \\
\text { ASTM C } \\
33-02\end{array}$ \\
\hline \# No.4 (4.75) & 95 & $95-100$ \\
\# No.8 (2.36) & 80 & $80-100$ \\
\# No.16 (1.18) & 59 & $50-85$ \\
\# No.30 (0.6) & 44 & $25-60$ \\
\# No.50 (0.3) & 18 & $5-30$ \\
\# No.100 (0.15) & 4 & $0-10$ \\
\hline
\end{tabular}

The natural sand supplied from AL-Ukhaider region was used as fine aggregate. The specific gravity and fineness modulus of sand are 2.65 and 3, respectively. The grading limits are according to ASTM C 33-02 [11] as given in Table 4.
SikaLightcrete 02 was used as a foaming agent to obtain lightweight foamed concrete by entraining a controlled amount of air bubbles to concrete mix. The use of 30 parts of water for dilution of foaming agent was prepared before using it.

Foam was produced in a laboratory using locally manufactured machine as shown in Plate 2. As the foam added to the mortar, they were blended in the mixer to get a homogeneous mixture, as shown in Plate 3.

Cut carbon fibers $8 \mathrm{~mm}$ were used in the lightweight foamed concrete. While, Monofilament polypropylene fibers (Sika fiber) were used in the lightweight foamed concrete mixes. The properties of the carbon and polypropylene fibers are listed in Table 5.

\section{Mix proportions}

The proportions of the foamed concrete mixes ( $\mathrm{C} 0-\mathrm{C} 6)$ were prepared using different volumetric fractions of fibers. However, the control or reference mix (CO) has been prepared to get the flowability range of $110 \pm 5 \%$. Besides, the foamed concrete reinforced with carbon fibers mixes were designated by the mixes $\mathrm{C} 1-\mathrm{C} 3$ due to the use of 0.5 , 1.0 and $1.5 \%$ of carbon fibers, respectively. The flow value was tested for each mix proportion. Furthermore, the hybridization of carbon fibers (CF) and polypropylene fibers (PPF) were presented in the mixes $\mathrm{C} 4-\mathrm{C} 5$. Such hybridization were as $1.0 \% \mathrm{CF}+0.5 \% \mathrm{PPF}$ and $0.5 \% \mathrm{CF}+1.0 \% \mathrm{PPF}$, respectively. Also, the flow values were recorded for these mixes. Lastly, the mix " $\mathrm{C6}$ " was prepared by the inclusion of 
Plate 2 Foaming machine

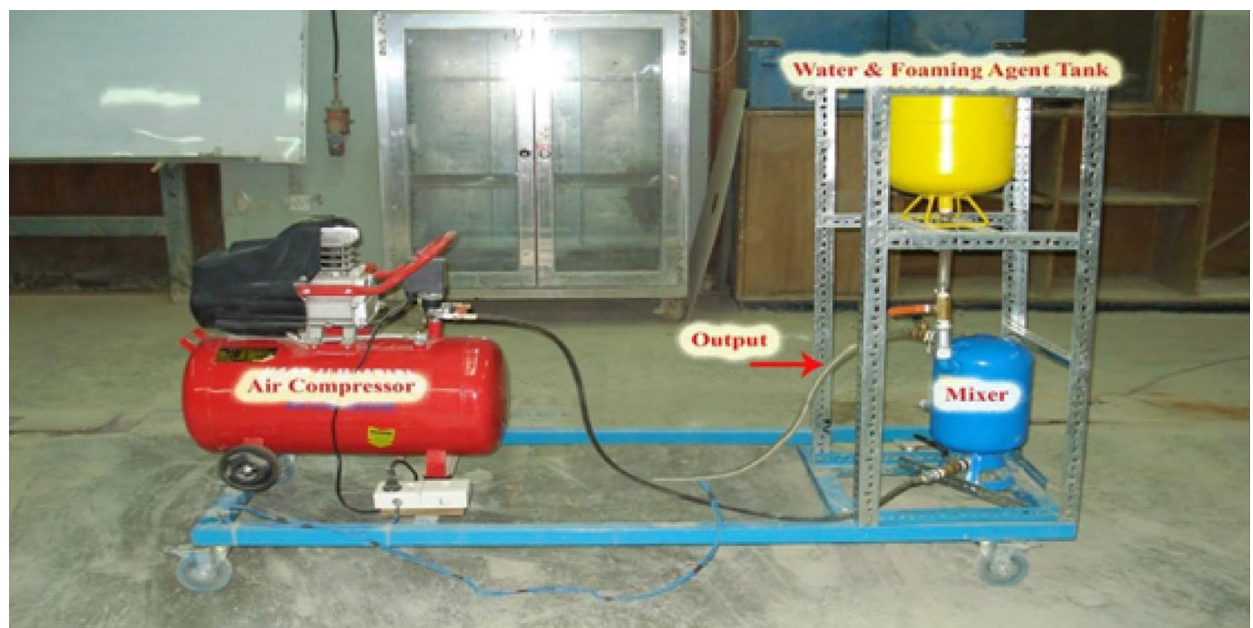

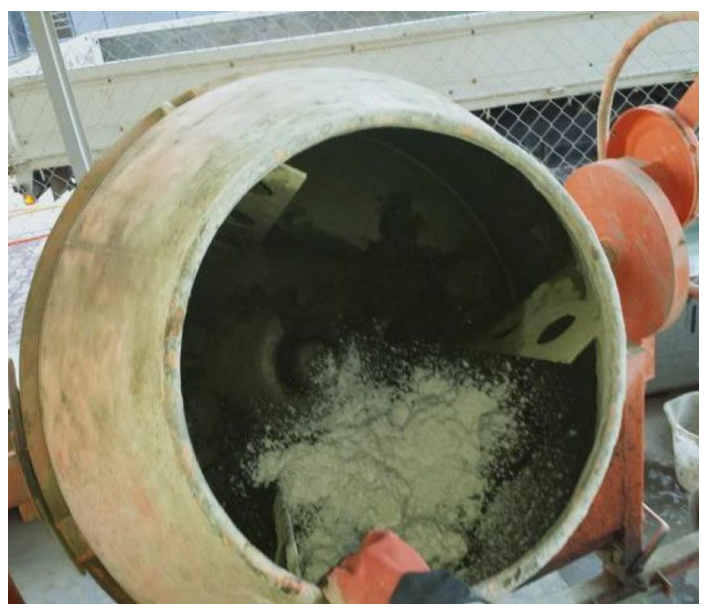

Plate 3 Addition of foam to the mix

Table 5 Properties of fibers

\begin{tabular}{lll}
\hline Fiber properties & Quantity for carbon fiber & $\begin{array}{l}\text { Quantity for } \\
\text { polypropylene } \\
\text { fiber }\end{array}$ \\
\hline Fiber length & $8 \mathrm{~mm}$ & $12 \mathrm{~mm}$ \\
Diameter & $7 \pm 2$ micron & $18 \mathrm{micron}$ \\
Aspect ratio & 1140 & 670 \\
Tensile strength & $3.5 \mathrm{GPa}$ & $500 \mathrm{MPa}$ \\
Young's Modulus & $230 \mathrm{GPa}$ & $3.5 \mathrm{GPa}$ \\
density & $1.7 \mathrm{~g} / \mathrm{cm}^{3}$ & $0.9 \mathrm{~g} / \mathrm{cm}^{3}$ \\
Chemical Resistance & $\mathrm{High}$ & $\mathrm{High}$ \\
Absorption & $\mathrm{Nil}$ & $\mathrm{Nil}$ \\
Melt Point & $3500^{\circ} \mathrm{C}$ & $160^{\circ} \mathrm{C}$ \\
Shape & $\mathrm{Chopped}$ strand & $\mathrm{Chopped}$ strand \\
\hline
\end{tabular}

SN Applied Sciences

a SPRINGER NATURE journal
1.5\% PPF in foamed concrete mix. The flowability was also measured for this mix. Table 6 shows the mix proportions of foamed concrete mixes reinforced with fibers. Whereas, Table 7 shows the weights of each proportion used in the control mix.

\section{Experimental work}

After 90 days curing at $20 \pm 2{ }^{\circ} \mathrm{C}$ for all specimens, the molds of $100 \mathrm{~mm}$ cubes were used for testing the compressive strength of the foamed concrete mixes according to BS 1881: part 116 [12], and the average of three cubes was used to determine such strength for each temperature regime. Whereas, the cylindrical molds $\phi 100 \times 200 \mathrm{~mm}$ were used for splitting tensile strength according to ASTM C 496 [13] and the average of three cylinders was used to determine such strength for each temperature regime. Three prisms of $40 \times 40 \times 160 \mathrm{~mm}$ were used to determine the flexural toughness for each temperature regime at age of 90 days. The flexural toughness test was carried out in accordance with ASTM C 1018 [14].

\section{Burning regime}

Firstly, the heating procedure of the specimens was done by applying them to different burning degrees, which were $200,250,300,350$ and $400^{\circ} \mathrm{C}$ at age of 90 days by using electrical furnaces. Each temperature was maintained for $1.5 \mathrm{~h}$ to achieve the burning steady state, due to the heating rate of furnace by $10^{\circ} \mathrm{C} / \mathrm{min}$. Secondly, the specimens were kept in the furnace for $24 \mathrm{~h}$ until the furnace cooled directly upon completing the burning cycle. Finally, the specimens were tested in compressive strength, splitting strength and flexural toughness. Figure 1 shows the scheme for the heating regime. Plate 4 shows the furnace 
Table 6 Mix proportions of foamed concrete mixes reinforced with fibers

\begin{tabular}{|c|c|c|c|c|c|c|c|c|c|}
\hline \multirow[t]{2}{*}{ Mix type } & \multicolumn{5}{|c|}{ Mix proportion } & \multicolumn{2}{|c|}{$\begin{array}{l}\text { Carbon } \\
\text { fiber \% }\end{array}$} & \multirow{2}{*}{$\begin{array}{l}\text { Flow } \\
\%\end{array}$} & \multirow{2}{*}{$\begin{array}{l}\text { Fresh density } \\
\mathrm{kg} / \mathrm{m}^{3}\end{array}$} \\
\hline & Cement & Sand & Water & Silica fume & Foam $\mathrm{Kg} / \mathrm{m}^{3}$ & $\mathrm{CF}$ & PPF & & \\
\hline $\mathrm{CO}$ & 0.9 & 1.9 & 0.38 & 0.1 & 1 & - & - & 110 & 1820 \\
\hline $\mathrm{C} 1$ & 0.9 & 1.9 & 0.35 & 0.1 & 1 & 0.5 & - & 80 & 1800 \\
\hline $\mathrm{C} 2$ & 0.9 & 1.9 & 0.37 & 0.1 & 1 & 1 & - & 75 & 1810 \\
\hline $\mathrm{C} 3$ & 0.9 & 1.9 & 0.41 & 0.1 & 1 & 1.5 & - & 60 & 1820 \\
\hline $\mathrm{C} 4$ & 0.9 & 1.9 & 0.38 & 0.1 & 1 & 1 & 0.5 & 80 & 1800 \\
\hline $\mathrm{C} 5$ & 0.9 & 1.9 & 0.37 & 0.1 & 1 & 0.5 & 1 & 80 & 1800 \\
\hline $\mathrm{C} 6$ & 0.9 & 1.9 & 0.37 & 0.1 & 1 & - & 1.5 & 90 & 1800 \\
\hline
\end{tabular}

Table 7 Mix proportions of the control mix

\begin{tabular}{lllllllll}
\hline Mix & Mix Proportion (cm:s) & w/cm & Cement $\left(\mathrm{kg} / \mathrm{m}^{3}\right)$ & Sand $\left(\mathrm{kg} / \mathrm{m}^{3}\right)$ & Water $\left(\mathrm{kg} / \mathrm{m}^{3}\right)$ & Silica fume $\left(\mathrm{kg} / \mathrm{m}^{3}\right)$ & Foam agent $\left(\mathrm{kg} / \mathrm{m}^{3}\right)$ & Voids $(\%)$ \\
\hline C0 & $(1: 1.9)$ & 0.34 & 485 & 1024 & 184 & 54 & 1 & 17 \\
\hline
\end{tabular}

Fig. 1 Scheme for the heating regime

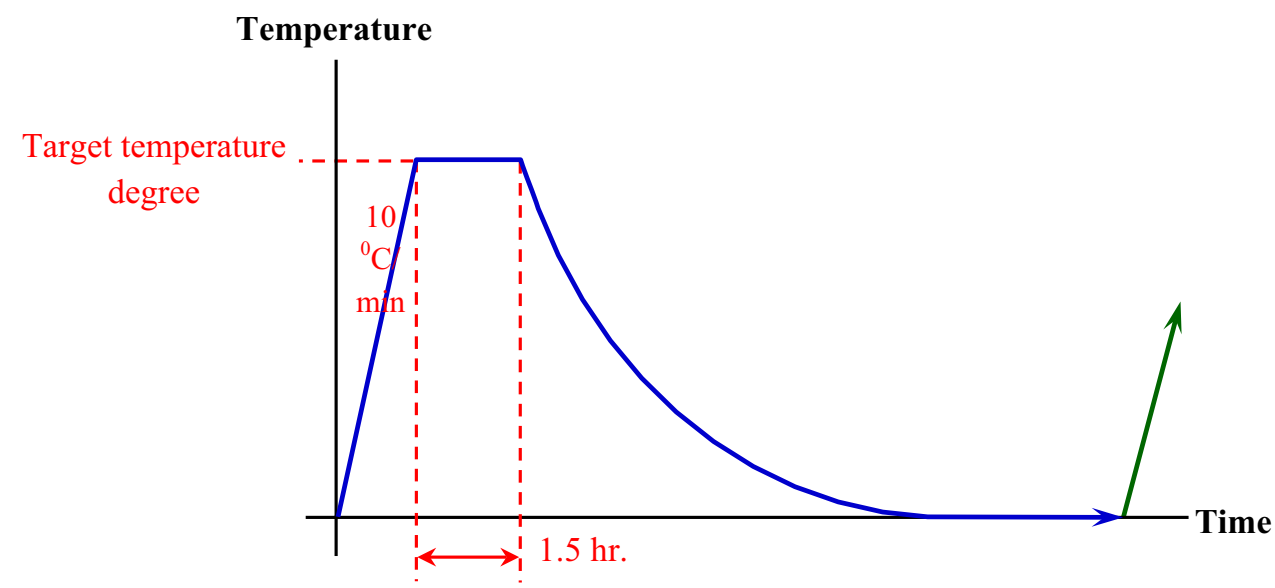

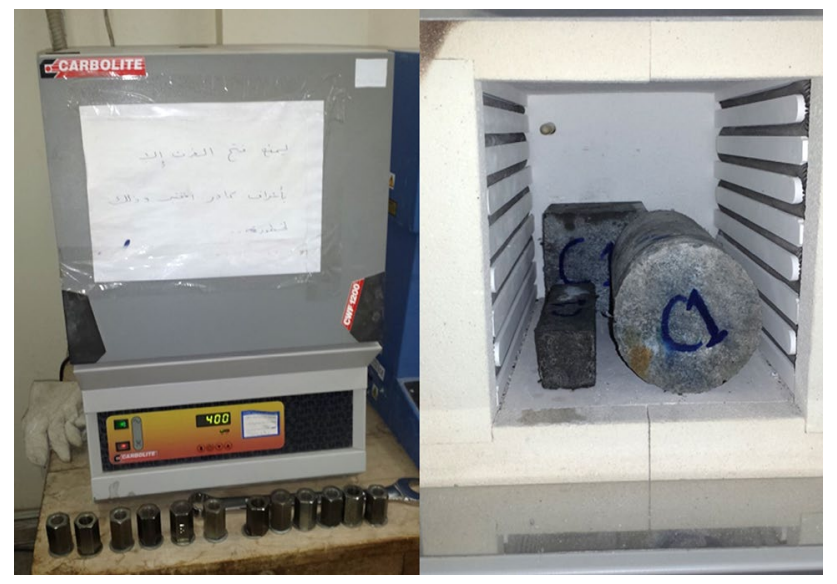

Plate 4 Furnace used in the heating regime used in such regime and the specimens exposed to different temperatures.

\section{Results and discussion}

\subsection{Compressive strength}

The results of residual compressive strengths for specimens after the exposure to different stages of temperature degrees are shown in Table 8.

Generally, the compressive strength of LWFC decreases with the higher temperatures. Within $200^{\circ} \mathrm{C}$, the changes of residual compressive strength values were slightly reduced with the temperature for all mixes. The decrease in compressive strength between 20 and $200^{\circ} \mathrm{C}$ corresponds to a reduction of the cohesion of the Van der Waal forces between the calcium silicate hydrate layers. This decreases the surface energy of calcium silicate hydrate and leads to 
Table 8 Residual compressive strengths for different temperature degrees

\begin{tabular}{lllllll}
\hline Mixes & \multicolumn{6}{l}{ Compressive strength (MPa) at age 90 days } \\
\cline { 2 - 6 } & $20{ }^{\circ} \mathrm{C}$ & $200{ }^{\circ} \mathrm{C}$ & $250{ }^{\circ} \mathrm{C}$ & $300^{\circ} \mathrm{C}$ & $350{ }^{\circ} \mathrm{C}$ & $400{ }^{\circ} \mathrm{C}$ \\
\hline C0 & 18.4 & 18.4 & 17.0 & 16.5 & 15.9 & 15.7 \\
C1 & 19.6 & 19.4 & 18.9 & 18.4 & 17.7 & 17.1 \\
C2 & 24.7 & 23.9 & 23.4 & 22.4 & 21.9 & 21.7 \\
C3 & 23.8 & 23.3 & 22.7 & 22.5 & 21.9 & 21.4 \\
C4 & 15.4 & 15.1 & 14.5 & 13.7 & 13.1 & 12.3 \\
C5 & 22.7 & 22.1 & 21.5 & 20.8 & 20.1 & 19.0 \\
C6 & 23.1 & 22.4 & 21.8 & 21.1 & 20.5 & 20.1 \\
\hline
\end{tabular}

the formation of silanol groups $(\mathrm{Si}-\mathrm{OH}: \mathrm{OH}-\mathrm{Si})$ that presents weaker bonding strength [8]. However, because this change only affects the concrete superficially, the reduction in concrete strength is not significant and the compressive strength of the foamed concrete mixes at $200^{\circ} \mathrm{C}$ still retained about $97 \%$ of the original unheated value. However, when the temperature ranged between 200 to $400^{\circ} \mathrm{C}$, decomposition of C-S-H gel and the sulfoaluminate phases caused cracks in the specimens. These cracks had significant effects on the compressive strength of foamed concrete [15].

When the temperature reached to $400{ }^{\circ} \mathrm{C}$, the reference mix of LWFC (C0) decreased strength by about $15 \%$ compared with the original strength at $20^{\circ} \mathrm{C}$. While, the LWFC reinforced with carbon fiber, the incorporation of $1.5 \%$ of carbon fibers exhibits the highest relative residual strength that is $90 \%$ of original strength at $20^{\circ} \mathrm{C}$. This is because the carbon fibers have high elastic modulus and high melting point. Therefore, carbon fibers bridge and resist cracking in the concrete, and can control the volume change of concrete due to rapid change of temperature and then mitigate the initiation and expansion of inner micro-defects of concrete $[15,16]$.

For LWFC reinforced with polypropylene fiber, the residual compressive strength at $400{ }^{\circ} \mathrm{C}$ was $80 \%$ of original compressive strength at $20^{\circ} \mathrm{C}$. This is the lowest relative residual strength obtained in this study. This can be related to the melting and vaporizing of polypropylene fiber that caused a weakness in concrete matrix [17]. For LWFC with hybrid fibers, the residual strengths at $400{ }^{\circ} \mathrm{C}$ were about $84 \%$ and $87 \%$ of original strength for $0.5 \% \mathrm{CF}+1 \% \mathrm{PPF}$ (C5) and $1 \% \mathrm{CF}+0.5 \% \mathrm{PPF}(\mathrm{C} 6)$, respectively. These results also indicate that Polypropylene fibers melt and vaporize due to the low melting point of such fibers, which induce micro-channel in the concrete [18].

\subsection{Flexural strength}

The results of residual flexural strengths for specimens after the exposure to different stages of temperature degrees are shown in Table 9.

Generally, the results of flexural strength are consistent with changes in the aforementioned other mechanical properties of LWFC. The flexural strength of all mixes reduced with the increasing of the temperatures. Once temperatures reached to $200^{\circ} \mathrm{C}$, calcium oxide was formed due to the dehydration of calcium hydroxide $\mathrm{Ca}(\mathrm{OH})_{2}$. Then, initial micro cracks is created as the chemically bound water molecules were scattered to the capillary pores. These micro-cracks were expanded adjacent the un-hydrated cement particles and led to a reduction in flexural strength of concrete as it is negatively influenced by cracks [19-21]. For reference LWFC (C0), the residual flexural strength at $200^{\circ} \mathrm{C}$ was $96 \%$ of the original strength at $20^{\circ} \mathrm{C}$ and at $400{ }^{\circ} \mathrm{C}$ was $59 \%$ of the original strength at $20^{\circ} \mathrm{C}$.

For LWFC reinforced with carbon fiber, the residual flexural strength at $200^{\circ} \mathrm{C}$ for $1.5 \%$ carbon fiber (C3) was $78 \%$
Table 9 Residual flexural strength for different temperature degrees

\begin{tabular}{lllllll}
\hline Mixes & \multicolumn{5}{l}{ Flexural strength (MPa) at age 90 days } \\
\cline { 2 - 6 } & $20{ }^{\circ} \mathrm{C}$ & $200^{\circ} \mathrm{C}$ & $250{ }^{\circ} \mathrm{C}$ & $300{ }^{\circ} \mathrm{C}$ & $350{ }^{\circ} \mathrm{C}$ & $400{ }^{\circ} \mathrm{C}$ \\
\hline C0 & 5.1 & 4.9 & 4.6 & 4.5 & 3.2 & 3.0 \\
C1 & 6.2 & 5.2 & 5.0 & 4.8 & 4.0 & 3.8 \\
C2 & 6.9 & 5.5 & 5.1 & 5.0 & 4.7 & 4.3 \\
C3 & 7.6 & 5.9 & 5.3 & 5.2 & 5.1 & 4.8 \\
C4 & 6.8 & 4.8 & 4.3 & 4.2 & 3.1 & 2.8 \\
C5 & 7.0 & 5.5 & 4.7 & 4.8 & 4.0 & 3.7 \\
C6 & 7.4 & 5.7 & 5.0 & 4.9 & 4.5 & 4.2 \\
\hline
\end{tabular}



toughness indices for prism $40 \times 40 \times 160 \mathrm{~mm}$, using ASTM C 1018
Table 10 Average flexural

\begin{tabular}{|c|c|c|c|c|c|c|c|c|c|c|c|c|}
\hline \multirow[t]{3}{*}{ Mixes } & \multicolumn{12}{|c|}{ Indices } \\
\hline & \multicolumn{2}{|c|}{$20^{\circ} \mathrm{C}$} & \multicolumn{2}{|c|}{$200^{\circ} \mathrm{C}$} & \multicolumn{2}{|c|}{$250^{\circ} \mathrm{C}$} & \multicolumn{2}{|c|}{$300^{\circ} \mathrm{C}$} & \multicolumn{2}{|c|}{$350^{\circ} \mathrm{C}$} & \multicolumn{2}{|c|}{$400^{\circ} \mathrm{C}$} \\
\hline & $I_{5}$ & $\mathrm{I}_{10}$ & $I_{5}$ & $I_{10}$ & $\mathrm{I}_{5}$ & $I_{10}$ & $\mathrm{I}_{5}$ & $\mathrm{I}_{10}$ & $I_{5}$ & $I_{10}$ & $\mathrm{I}_{5}$ & $I_{10}$ \\
\hline $\mathrm{CO}$ & 1.0 & 1.0 & 1.0 & 1.0 & 1.0 & 1.0 & 1.0 & 1.0 & 1.0 & 1.0 & 1.0 & 1.0 \\
\hline $\mathrm{C} 1$ & 2.2 & 2.2 & 2.3 & 2.3 & 2.2 & 2.2 & 2.1 & 2.1 & 1.8 & 1.8 & 2.0 & 2.0 \\
\hline $\mathrm{C} 2$ & 3.3 & 3.7 & 3.0 & 3.7 & 2.5 & 2.5 & 2.2 & 2.3 & 2.3 & 2.4 & 2.4 & 2.4 \\
\hline C3 & 3.8 & 4.1 & 3.3 & 3.8 & 2.9 & 3.1 & 2.8 & 3.5 & 2.6 & 2.8 & 2.5 & 2.7 \\
\hline C4 & 3.7 & 4.6 & 1.8 & 1.8 & 1.5 & 1.5 & 1.3 & 1.3 & 1.0 & 1.0 & 1.0 & 1.0 \\
\hline C5 & 3.4 & 4.3 & 3.1 & 4.6 & 2.2 & 2.2 & 2.2 & 2.2 & 1.9 & 1.9 & 1.7 & 1.7 \\
\hline C6 & 3.3 & 4.1 & 2.9 & 3.9 & 2.3 & 2.3 & 2.2 & 2.4 & 2.5 & 2.6 & 2.1 & 2.5 \\
\hline
\end{tabular}

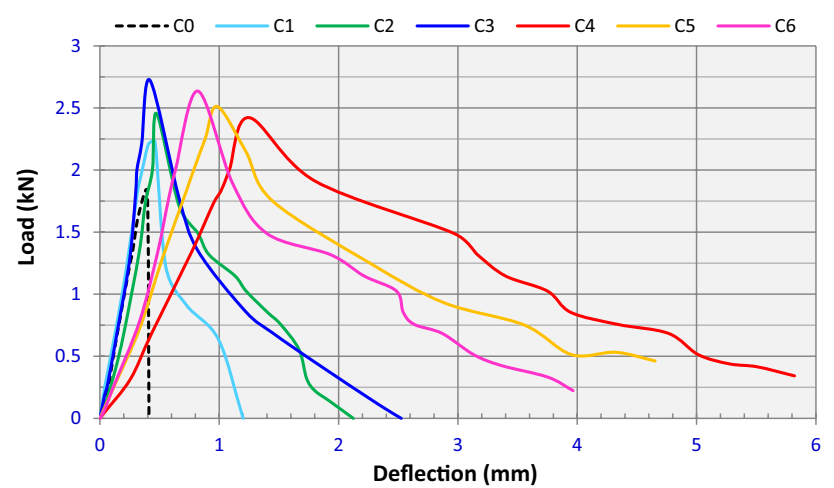

Fig. 2 Load-deflection curve for LWFC at normal temperature degree $\left(20^{\circ} \mathrm{C}\right)$

of the original strength at $20^{\circ} \mathrm{C}$. Whereas at $400^{\circ} \mathrm{C}$, the residual splitting tensile strength for such mix was $63 \%$ of the original strength at $20^{\circ} \mathrm{C}$.

On the other hand, for the LWFC reinforced with polypropylene fiber, the result of residual flexural strength at $200{ }^{\circ} \mathrm{C}$ for $1.5 \%$ polypropylene fiber (C4) was $71 \%$ of the original strength at $20^{\circ} \mathrm{C}$. At $400{ }^{\circ} \mathrm{C}$, the residual splitting tensile strength for such mix was $41 \%$ of the original strength at $20^{\circ} \mathrm{C}$.

For LWFC reinforced with hybrid fibers, the residual flexural strengths at $400{ }^{\circ} \mathrm{C}$ were $53 \%$ and $57 \%$ of original strength for $0.5 \% \mathrm{CF}+1 \%$ PPF (C5) and $1 \% \mathrm{CF}+0.5 \% \mathrm{PPF}$ (C6), respectively. Again, this behavior also related to same causes mentioned in the previous section.

\subsection{Flexural toughness}

The results of flexural toughness by using $40 \times 40 \times 160 \mathrm{~mm}$ prisms in three-point bending test at normal temperature and after exposing to elevated temperatures are shown in Table 10. The load-deflection curves for all mixes at normal temperature and after the exposure to high temperatures are shown in Figs. 2, 3, 4, 5, 6 and 7.

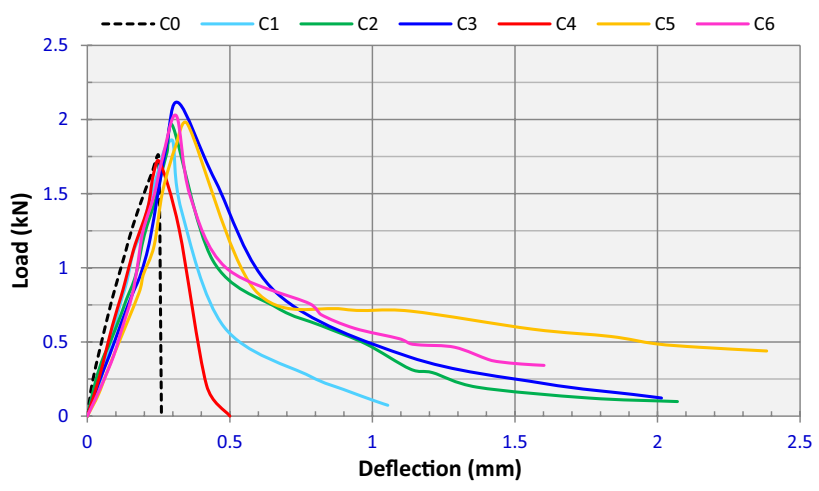

Fig. 3 Load-deflection curve for LWFC after exposure to $200^{\circ} \mathrm{C}$

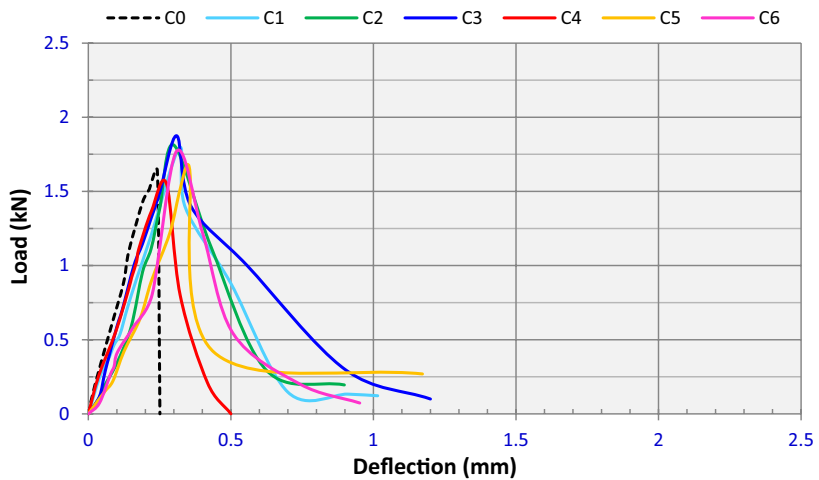

Fig. 4 Load-deflection curve for LWFC after exposure to $250^{\circ} \mathrm{C}$

Flexural toughness of concrete is adversely influenced by cracks either on a macro or on micro scale, which are caused by high temperatures $[19,20]$.

However, it can be seen that the flexural toughness of all mixes decreased clearly with the increasing of the temperatures. For LWFC mixes reinforced with carbon fiber, the results of toughness indices $\left(I_{5}\right.$ and $\left.I_{10}\right)$ were slightly decreased with increasing of temperature degrees, the toughness indices 15 and 110 for $1.5 \%$ carbon fiber (C 3 ) 


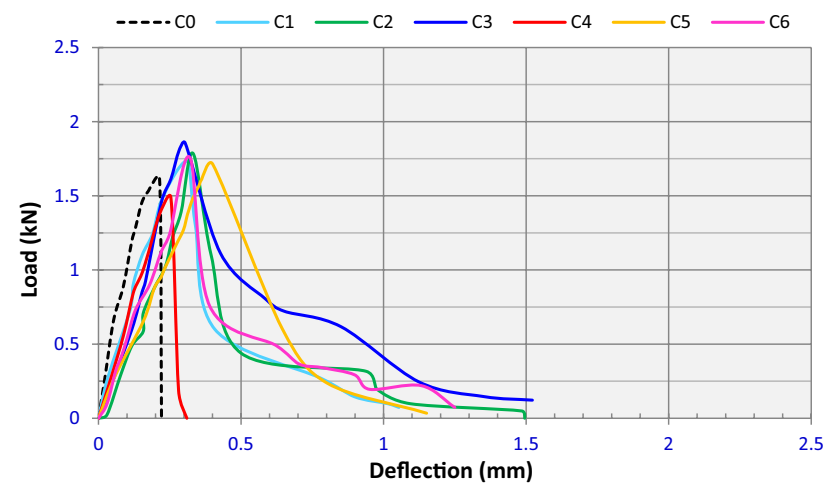

Fig. 5 Load-deflection curve for LWFC after exposure to $300^{\circ} \mathrm{C}$

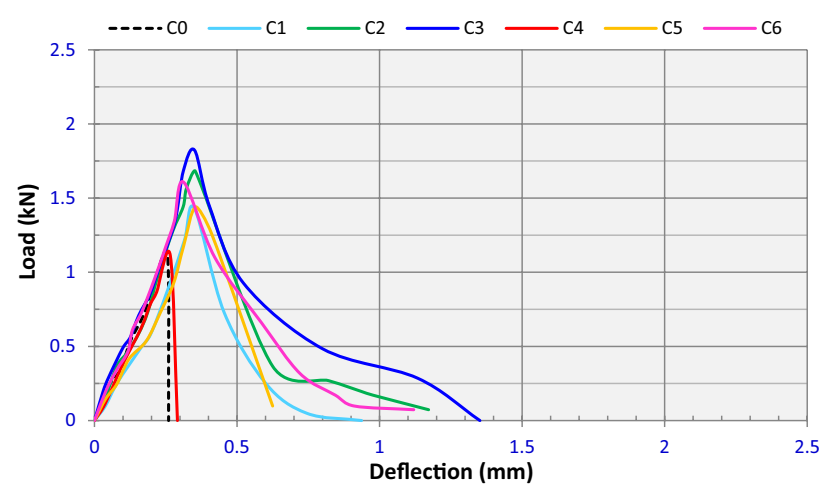

Fig. 6 Load-deflection curve for LWFC after exposure to $350^{\circ} \mathrm{C}$

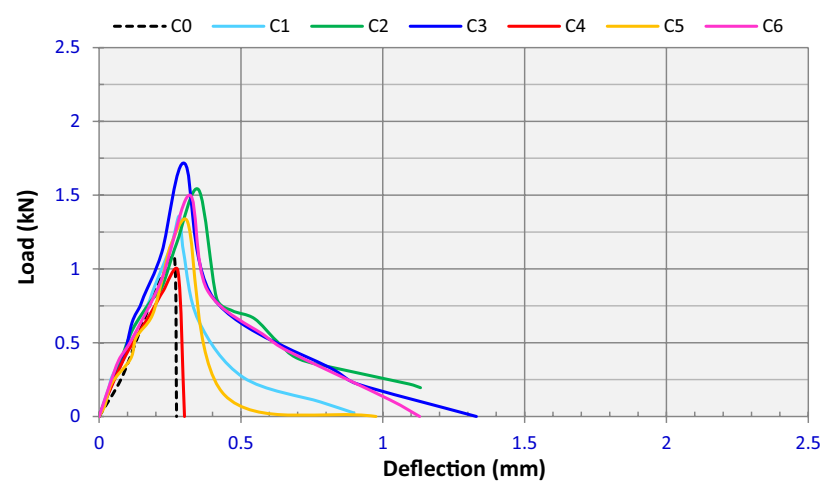

Fig. 7 Load-deflection curve for LWFC after exposure to $400{ }^{\circ} \mathrm{C}$

were 3.3 and 4.1, respectively, at normal temperature degree. Whereas, the toughness indices 15 and 110 for such mix were 2.5 and 2.7 , respectively, at $400^{\circ} \mathrm{C}$.

For LWFC mix reinforced with polypropylene fiber, the results of toughness indices $\left(I_{5}\right.$ and $\left.I_{10}\right)$ were significantly dropped with the increasing of the temperatures, the toughness indices 15 and 110 for $1.5 \%$ polypropylene fiber (C4) were 3.7 and 4.6, respectively, at normal temperature degree. The toughness indices $I 5$ and $I 10$ for such mix were 1.8 for both indices at $200^{\circ} \mathrm{C}$. At temperature $350^{\circ} \mathrm{C}$, the toughness indices 15 and 110 were 1.0. This means, that the polypropylene fibers incorporated in LWFC were fully melted and vaporized.

On the other hand, the LWFC mixes reinforced with hybrid fibers exhibited superior flexural toughness compared to the mono fibers. The use of $1 \% \mathrm{CF}+0.5 \% \mathrm{PPF}$ (C6) gave flexural toughness indices $I_{5}$ and $I_{10}$ as 3.3 and 4.1, respectively, at normal temperature degree. Whereas, the toughness indices 15 and 110 for such mix were 2.1 and 2.5, respectively, at $400{ }^{\circ} \mathrm{C}$. Again, this behavior also related to same causes mentioned in the previous section. This observation can be attributed to the fact that the carbon fibers which are stiffer than polypropylene in the hybrid fiber system provide reasonable first crack strength and ultimate strength. Whereas, polypropylene fibers are relatively flexible and lead to improve toughness and strain capacity in the post-crack zone $[21,22]$.

\subsection{Splitting tensile strength}

The results of residual splitting tensile strengths for specimens after the exposure to different stages of temperature degrees are shown in Table 11.

Generally, the tensile strength is relatively more sensitive to such cracks than that of compressive strength of LWFC $[15,16]$.

The reduction in the splitting tensile strength of LWFC occurred after $200^{\circ} \mathrm{C}$. This behavior is attributed to free water and chemically bound water in the LWFC mixes that evaporated from the porous body, generating micro cracks in the matrix [8]. For reference mix (C0), the residual splitting tensile strength at $200^{\circ} \mathrm{C}$ was $90 \%$ of the original strength at $20^{\circ} \mathrm{C}$. After $250^{\circ} \mathrm{C}$, a significant drop in tensile strength was occurred.

At $400{ }^{\circ} \mathrm{C}$, the splitting tensile strength was about $50 \%$ of the initial value. This is because the chemical constitution of LWFC started to break down due to decomposition of the C-S-H and sulfoaluminate phases [23].

For LWFC reinforced with carbon fiber, the residual splitting tensile strength at $200{ }^{\circ} \mathrm{C}$ for $1.5 \%$ carbon fiber (C3) was $91 \%$ of the original strength at $20^{\circ} \mathrm{C}$. Whereas, at $400{ }^{\circ} \mathrm{C}$, the residual splitting tensile strength for such mix was $66 \%$ of the original strength at $20^{\circ} \mathrm{C}$, which is the highest value of relative strength at $400^{\circ} \mathrm{C}$. This is related to the ability of carbon fiber up to some high elevated temperatures to restrict the initiation and expansion of cracking in the concrete due to its tensile resistance, which maintained higher residual strengths of concretes after the exposure to high temperature [17-19, 24].

On the other hand, for the LWFC reinforced with polypropylene fiber exposed to high elevated temperatures, 
Table 11 Residual splitting tensile strength for different temperature degrees

\begin{tabular}{lllllll}
\hline Mixes & \multicolumn{7}{l}{ Splitting tensile strength (MPa) at age 90 days } \\
\cline { 2 - 6 } & $20{ }^{\circ} \mathrm{C}$ & $200{ }^{\circ} \mathrm{C}$ & $250{ }^{\circ} \mathrm{C}$ & $300{ }^{\circ} \mathrm{C}$ & $350{ }^{\circ} \mathrm{C}$ & $400{ }^{\circ} \mathrm{C}$ \\
\hline $\mathrm{C} 0$ & 2.0 & 1.8 & 1.6 & 1.2 & 1.2 & 1.0 \\
$\mathrm{C} 1$ & 2.1 & 1.9 & 1.8 & 1.5 & 1.3 & 1.2 \\
$\mathrm{C} 2$ & 2.8 & 2.5 & 2.5 & 2.1 & 1.9 & 1.7 \\
$\mathrm{C} 3$ & 3.2 & 2.9 & 2.7 & 2.4 & 2.3 & 2.1 \\
$\mathrm{C} 4$ & 2.2 & 1.7 & 1.6 & 1.5 & 1.2 & 1.0 \\
$\mathrm{C} 5$ & 2.3 & 2.2 & 2.1 & 1.8 & 1.6 & 1.3 \\
$\mathrm{C} 6$ & 3.1 & 2.9 & 2.5 & 2.3 & 2.0 & 1.9 \\
\hline
\end{tabular}

the results exhibit worse influence on the splitting tensile strength than that of carbon fiber mixes. At $200^{\circ} \mathrm{C}$, the residual splitting tensile strength of $1.5 \%$ polypropylene fiber (C4) was $77 \%$ of the original strength at $20^{\circ} \mathrm{C}$. This is also related to the low melting point of polypropylene fiber. When $400^{\circ} \mathrm{C}$ was reached, the residual splitting tensile strength was $45 \%$ of the original strength at $20^{\circ} \mathrm{C}$. For LWFC reinforced with hybrid fibers, the residual splitting tensile strengths at $400{ }^{\circ} \mathrm{C}$ were $57 \%$ and $61 \%$ of original strength for $0.5 \% \mathrm{CF}+1 \% \mathrm{PPF}(\mathrm{C} 5)$ and $1 \% \mathrm{CF}+0.5 \% \mathrm{PPF}$ (C6), respectively. This behavior also related to the property of polypropylene fibers to be melted and vaporized due to the low melting point. Whereas, the carbon fibers bridged and resisted cracking in the concrete, and enhanced the residual tensile strength of LWFC.

\section{Conclusions}

1. The flexural toughness of foamed concrete is enhanced with fibers, the use of carbon fibers exhibits more effect to bridge micro cracks. Whereas, the polypropylene fibers have a noticeable improvement on macro cracks.

2. The compressive strength of LWFC decreases with the increasing temperature. The changes of strength properties' values may be reduced slightly with the temperature up to $250^{\circ} \mathrm{C}$. However, the highest effects on compressive strength appeared once the temperature raised to $400^{\circ} \mathrm{C}$.

3. The flexural tensile strengths of LWFC decrease gradually with the increasing temperature. At $400^{\circ} \mathrm{C}$, the lowest residual strengths for both tests can be obtained with a control LWFC mix and for the LWFC reinforced with mono polypropylene fibers.

4. The LWFC mix reinforced with polypropylene fiber exhibits more sensitive to elevated temperature than LWFC mixes reinforced with carbon fiber due to low melting point of polypropylene fiber.

5. The flexural toughness of LWFC is enhanced with fibers, the use of carbon fibers exhibits more effect to bridge pre-crack zone. Whereas, the polypropylene fibers have a noticeable improvement in post-crack zone.

6. The toughness indices (I5 and I10) have decreased with increasing of temperature degrees for the LWFC reinforced with carbon fibers. Whereas, the toughness indices (I5 and I10) for the LWFC reinforced with polypropylene fibers are significantly dropped with the increasing of the temperatures. This means, that the polypropylene fibers are fully melted and vaporized after exposing to high elevated temperature.

7. The Splitting and flexural tensile strengths of LWFC decrease gradually with the increasing temperature. At $400^{\circ} \mathrm{C}$, the lowest residual strengths for both tests can be obtained with a control LWFC mix and for the LWFC reinforced with mono polypropylene fibers.

Acknowledgements The authors would express their thanks to the Building and Construction department staff in University of Technology-Baghdad for supporting their research. Special thanks to the technical staff in concrete and structural lab in the department.

\section{Compliance with ethical standard}

Conflict of interest The authors declare that they have no conflict of interest.

\section{References}

1. Lim SK, Tan CS, Zhao X, Ling TC (2015) Strength and toughness of lightweight foamed concrete with different sand grading. Korean Soc Civ Eng 19(7):2191-2197

2. Dhengare S.W, Dandge A.L, Nikhade H.R (2015) Cellular Lightweight Concrete. J Int Assoc Adv Technol Sci 16

3. Soleimani T, Merati AA, Latifi M, Ramezanianpor AA (2013) Inhibition of cracks on the surface of cement mortar using estabragh fibers. Adv Mater Sci Eng 2013:1-5

4. Darole JS, Kulkarni VP, Shaikh AP, Gite BE (2013) Effect of hybrid fiber on mechanical properties of concrete. Int J Eng Res Appl 3(4):1408-1411

5. Mydin MAO, Wang YC (2010) An experimental investigation of mechanical properties of lightweight foamed concrete subjected to elevated temperatures up to $600^{\circ} \mathrm{C}$. Concr Res Lett 1:4 
6. Song W, Yin J (2016) Hybrid effect evaluation of steel fiber and carbon fiber on the performance of the fiber reinforced concrete. Materials 9:8

7. Dawood ET, Hamad AJ (2015) Toughness behavior of high performance lightweight foamed concrete reinforced with hybrid fibers. Struct Concr J 16(4):496-507

8. Kearsley EP, Mostert HF (2005) The use of foamed concrete in refractories. In: Conference proceedings, use of foamed concrete in construction, Institution of Civil Engineers (ICE) Publishing, pp 89-96

9. Tanyildizi $\mathrm{H}$ (2008) Effect of temperature, carbon fibers, and silica fume on the mechanical properties of lightweight concretes. New Carbon Mater 23(4):339-344

10. Iraqi Standard Specification (IQS), No.5/1984, Portland cement. Central Organization for Standardization \& Quality Control, Baghdad, Iraq

11. ASTM C 33 (2008) Standard specification for concrete aggregates. Annual book of ASTM standards, vol 04.02

12. British Standard Institution, Compressive strength of test specimens. B.S. 1881, Part 116, 1983

13. ASTM C 496 (2017) Standard test method for splitting tensile strength of cylindrical concrete specimens, Annual book of ASTM standards vol 04.02

14. ASTM C 1018 (1997) Standard test method for flexural toughness and first-crack strength of fiber-reinforced concrete (using beam with third-point loading). Annual book of ASTM standards vol 04.02

15. Chen B, Liu J (2004) Residual strength of hybrid-fiber-reinforced high-strength concrete after exposure to high temperatures. Cem Concr Res 34(6):1065-1069

16. Ayudhya BIN (2016) Comparison of compressive and splitting tensile strength of autoclaved aerated concrete (AAC) containing water hyacinth and polypropylene fiber subjected to elevated temperatures. Mater Struct 49(4):1455-1468
17. Akca AH, Zihnioğlu NÖ (2013) High performance concrete under elevated temperatures. Constr Build Mater 44:317-328

18. Narayanan N, Ramamurthy K (2000) Structure and properties of aerated concrete: a review. Cem Concr Compos 22(5):321-329

19. Ding Y, Azevedo C, Aguiar JB, Jalali S (2012) Study on residual behavior and flexural toughness of fiber cocktail reinforced selfcompacting high performance concrete after exposure to high temperature. Constr Build Mater 26(1):21-31

20. Soleimanzadeh S, Mydin MAO (2013) Influence of high temperatures on flexural strength of foamed concrete containing fly ash and polypropylene fiber. Int J Eng 26(2):117-126

21. Taylor HFW (1997) Cement Chemistry, 2nd edn. Thomas Telford Publishing, London

22. Abdul-Rahman MB, Al-attar AA, Younus AM (2018) Elevated temperature effects on the behavior of one-way fibrous reinforced concrete slabs. Int J Eng Technol 7(437):179-184

23. Neville AM, Brooks JJ (2010) Concrete Technology, 2nd edn. Prentice Hall, Pearson Education

24. Mydin MAO, Soleimanzadeh S (2012) Effect of polypropylene fiber content on flexural strength of lightweight foamed concrete at ambient and elevated temperatures. Pelagia Res Libr Adv Appl Sci Res 3(5):2837-2846

25. ASTM C 1437 (2015) Standard test method for flow of hydraulic cement mortar. Annual book of ASTM standards vol 04.02

26. ASTM C 143 (2015) Standard test method for slump of hydrauliccement concrete. Annual book of ASTM standards vol 04.02

27. Topcu IB, Canbaz M (2007) Effect of different fibers on the mechanical properties of concrete containing fly ash. Constr Build Mater 21:1486-1491

Publisher's Note Springer Nature remains neutral with regard to jurisdictional claims in published maps and institutional affiliations. 